九州大学学術情報リポジトリ

Kyushu University Institutional Repository

\title{
Determination of Major Influential Factors Impacting Farm Returns and Total Productivity of Rice in Myanmar
}

Thu, Myint

Graduate School of Bioresource and Bioenvironmental Sciences, Kyushu University

Shinkai, Shoji

Faculty of Agriculture, Kyushu University

Hotta, Kazuhiko

Faculty of Agriculture, Kyushu University

https://doi.org/10.5109/9307

出版情報：九州大学大学院農学研究院紀要. 52 (1)，pp.213-219，2007-02-28. Faculty of Agriculture, Kyushu University

バージョン :

権利関係 : 


\title{
Determination of Major Influential Factors Impacting Farm Returns and Total Productivity of Rice in Myanmar
}

\author{
Myint THU ${ }^{1 *}$, Shoji SHINKAI ${ }^{2}$, Kazuhiko HOTTA ${ }^{2}$ \\ Laboratory of Farm Management, Division of International Agricultural Resource Economics and Business \\ Administration, Department of Agricultural and Resource Economics, Faculty of Agriculture, \\ Kyushu University, Fukuoka 812-8581, Japan \\ (Received September 30, 2006 and accepted December 1, 2006)
}

\begin{abstract}
On the determination of net farm returns on rice production, seasonal price seems to be an important factor in Myanmar. The achievement of high income is partially offset by low seasonal price. Under the same level of yield received from rice production, the farmers who can access the higher price obtained more profit. In the present rice production system, the total productivity is mainly being impacted by increased cropping intensity and the yield per unit area. Although the growth rate of yield seems to be impressive in the moment, there has been much potential to obtain much more yield by using essential agricultural inputs. The effect of inputs used doesn't show any evidence on total productivity of rice. Especially, the utilization of chemical fertilizer and the effect of loans distribution are not likely to be efficient to obtain higher productivity. Since the analyses suggest that both the price elasticity of demand and the income elasticity of demand are inelastic, it is reasonable to assume that rice is normal good in Myanmar and thus demand is not very sensitive to income changes. Moreover, the farmers would achieve higher revenue if the price rises to some extent.
\end{abstract}

\section{INTRODUCTION}

The agricultural economy of Myanmar has been transforming into market oriented economic system since the late 1980s. According to the literature survey by Rozelle and Swinnen (2004), in East Asia, economic planning keeps agricultural produce prices artificially low, while in Eastern Europe and Central Asia, it keeps price artificially high. Efficient and adaptable pricing policy is likely to enhance the agricultural output. It can be more prominent in the countries like China and Vietnam that the agricultural performance has been most impressive under market oriented economic system. High growth in agricultural output and productivity partly accounted for the rapid reduction in rural poverty of developing countries. Even though Myanmar was the world's largest exporter of rice in the pre-World War II period, the export of rice has been declining after 2001. There have been several things to be considered to secure higher productivity and surplus of rice for export. Among them, the availability of accessing incentive price and the extent of agricultural inputs used seem to be important in order to offset the decline in both net farm returns and rice productivity. Therefore, the effect of rice price on net farm income attainment should be considered

\section{Objectives of the study}

To determine the seasonal index of rice price in Myanmar in order for the farmers to obtain good returns

\footnotetext{
${ }^{1}$ Laboratory of Farm Management, Division of International Agricultural Resource Economics and Business Administration, Department of Agricultural and Resource Economics, Graduate School of Bioresource and Bioenvironmental Sciences, Kyushu University.

${ }^{2}$ Faculty of Agriculture, Kyushu University

* Corresponding author (E-mail: thumyin@gmail.com)
}

on rice production.

To clarify the demand schedule of rice

To identify the factors affecting total rice productivity in Myanmar from 1987 to 2003.

\section{DESCRIPTION OF THE DATA}

The monthly data of rice price was used in order to determine the seasonal index of rice price for each month. This monthly data ranging from the January of 2001 to December of 2004 was obtained from the book, namely "Selected Monthly Economics Indicators, published by Central Statistical Organization, Yangon, Union of Myanmar. The fluctuation of monthly price from 2001 to 2004 can be observed by the figure $1 \mathrm{a}$ to $1 \mathrm{~d}$.

In order to have better understanding of major factors influencing total rice productivity throughout the period from 1987 to 2003, the yearly data of fertilizer utilization, cropping intensity in percentage, the amount of loan distributed by Myanmar Agriculture and Development Bank (MADB) and yield per unit area and the total productivity of rice, which is used as a dependent variable, were also acquired from the title of "Agricultural Statistics"(1999), Statistical Year Book (2001) and Myanmar Agriculture at a Glance, 2003, 2004 and 2005. The trend of each variable is elucidated in figure $2 \mathrm{a}$ and $2 \mathrm{~b}$.

\section{METHODOLOGY}

\section{The relationship between the seasonal price and net farm returns on Rice production}

Figure (3) is constructed by using monthly data of rice price from 2001 to 2004. This data is subject to systemic variation originating in "seasonal" factors- that is, factors which recur with predictable regularity over short period of time. A seasonal factor may be 


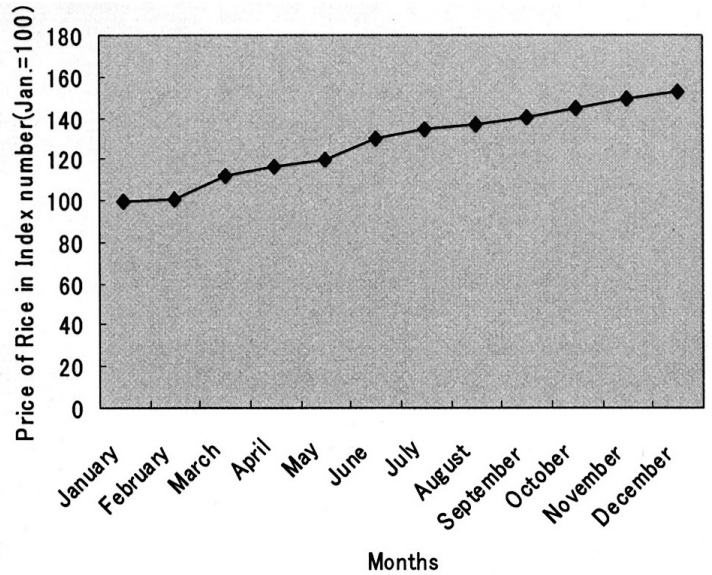

Fig. 1a. Monthly price of rice for 2001.

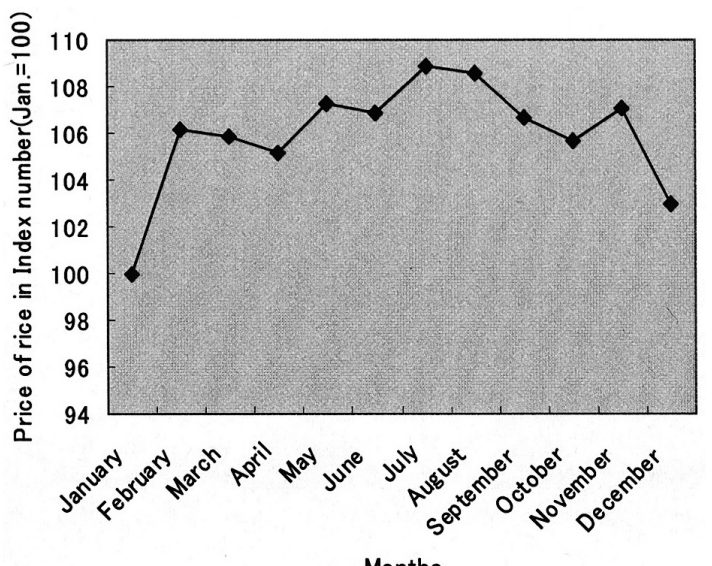

Fig. 1c. Monthly price of rice for 2003.

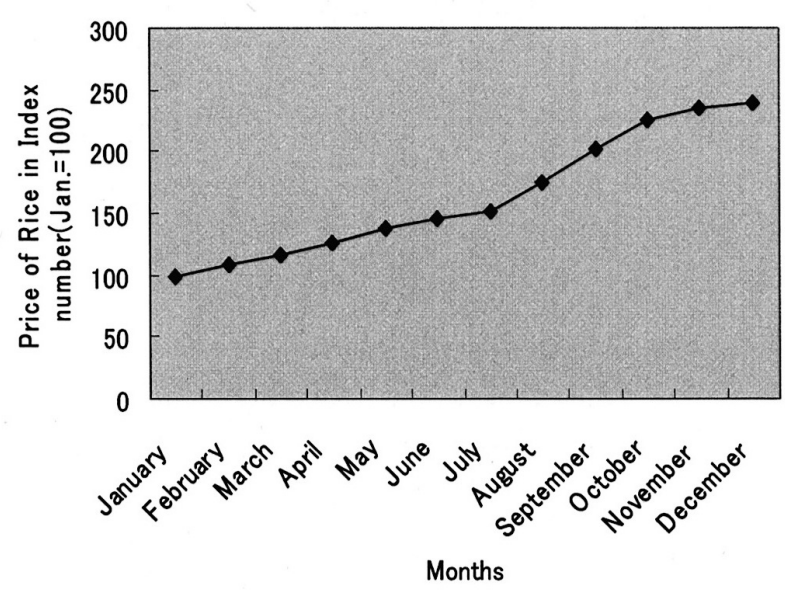

Fig. 1b. Monthly price of rice for 2002.

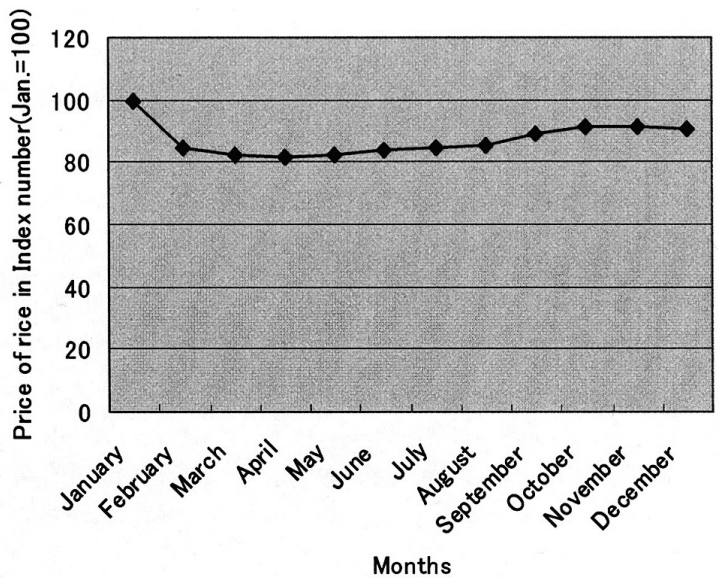

Fig. 1d. Monthly price of rice for 2004 .

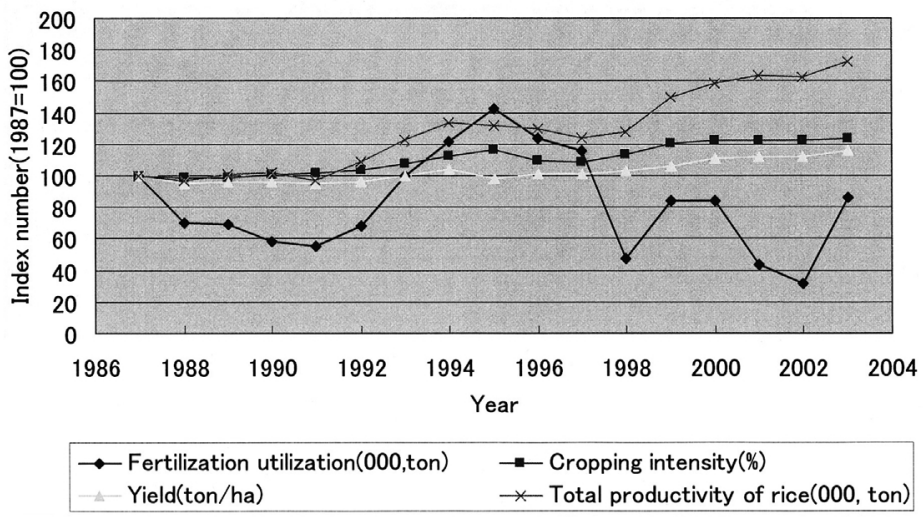

Fig. 2a. The trend of influential variables moving from 1987 to 2003.

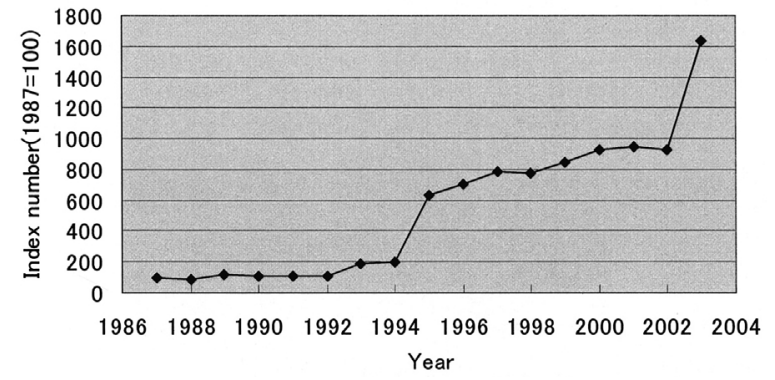

Fig. 2b. The amount of loan provided by MADB. 
Seasonal index of rice price in Myanmar

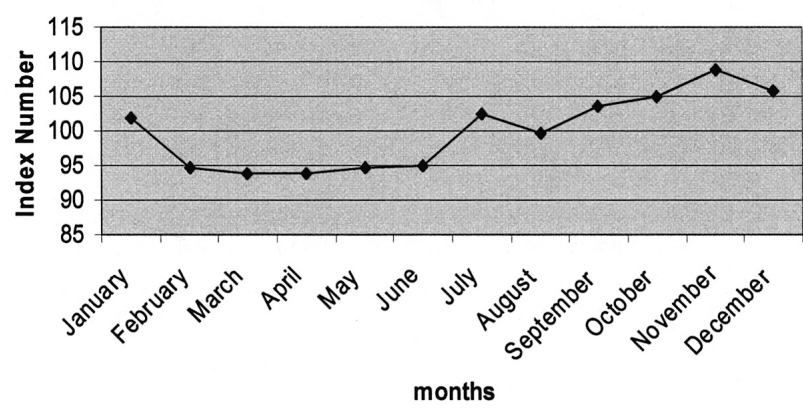

Source: Central Statistical Organization, Yangon, Myanmar.

Fig. 3. Seasonal index of rice price from 2001 to 2004.

described as a force acting persistently at regular time interval of one year or less and causing systematic changes in the variable being measured. This figure shows the historical knowledge of the past seasonal factor in a particular time series. This may be done simply because the knowledge is interesting itself, or because the pattern may be expected to repeat itself (to some degree) in the future. Therefore, it may be of use in forecasting future values of the time series.

\section{Demand schedule of rice for Myanmar}

The ordinary least square estimating procedure was used with price taken as the dependent variable, and income and consumption taken as independent, where consumption is defined as the product of average consumption per capital and total population of respective year. To the extent that the explanatory variables are not in fact predetermined, the lease squares regression coefficients are biased estimates of the true demand function coefficients. The Income Elasticity of Demand and the Price Elasticity of Demand are shown in Table 1 for specific year of the period from 1997 to 2003.

Determination of the price elasticity of demand for rice from 1997 to 2003.

Based upon the schedule of demand, the demand function is determined. If we assume linear demand function, the functional relationship between price and quantity is determined by using seven years data and establishing the linear function.

$$
P=f(x)=-1392.89+0.15 X
$$

Where, $\mathrm{P}=$ the price $(\mathrm{kyat} / \mathrm{kg})$

$\mathrm{X}=$ the amount of consumption in quantity $(\mathrm{kg})$

The elasticity of demand can be determined by making the derivative of linear function.

$$
\frac{\partial P}{\partial X}=0.15
$$

Since $P=f(x)$ and $X=g(p)$ are inverse functions, we can determine $\mathrm{dx} / \mathrm{dp}$ by using the rule of determining derivatives of inverse functions.

Thus

$$
\frac{\partial X}{\partial P}=\frac{1}{\frac{\partial P}{\partial X}}=\frac{1}{0.15}=6.67
$$

The price elasticity of demand $=\frac{\partial X}{\partial P} * \frac{P}{X}$

$$
\begin{aligned}
& =6.67 * 104.02 / 9684.48 \\
& =0.07
\end{aligned}
$$

where, $p=$ the mean value of price

$\mathrm{X}=$ the mean value of rice consumption

Determination of income elasticity of demand for rice from 1997 to 2003.

Income elasticity of demand is used to see how sensitive the demand for a good is to an income change. The higher the income elasticity, the more sensitive demand for a good is to income change. Very low income elasticity suggests that the change in a consumer's income has little influence on demand.

In order to determine the income elasticity of demand for rice, the demand function is assumed to be linear and taking the amount of consumption as dependent.

we have

$$
\mathrm{Y}=\beta_{0}+\beta_{1} \mathrm{X}+\mathrm{u}_{1}
$$

Where $\quad \mathrm{Y}=$ the amount of consumption in kilogram

$$
\mathrm{X}=\text { income per capital (kyat) }
$$

$\boldsymbol{\beta}_{0}, \boldsymbol{\beta}_{1}$ are parameters to be estimated;

$\mathrm{u}_{1}$ is unobserved disturbance or error term.

The least squares estimates give

$$
\mathrm{Y}=9379.07+0.01 \mathrm{X}
$$

The elasticity of demand can be determined by making the derivative of linear function.

$$
\frac{\partial y}{\partial X}=0.01
$$

the income elasticity of demand for rice $=\frac{\partial Y}{\partial X} * \frac{X}{Y}$ $=0.01 * 22187 / 9684.48$

Table 1. Rice price, per capital GDP and consumption of rice from 1997 to 2003

\begin{tabular}{ccccc}
\hline Year & $\begin{array}{c}\text { rice } \\
\text { price (Kyat/kg) }\end{array}$ & $\begin{array}{c}\text { per capita } \\
\text { GDP (kyat) }\end{array}$ & $\begin{array}{c}\text { consumption } \\
\text { (million, kg) }\end{array}$ & $\begin{array}{c}\text { income elasticity of } \\
\text { demand }\end{array}$ \\
\hline 1997 & 30.9032 & 1619 & 9001.6 & 0.002 \\
1998 & 47.65885 & 1650 & 9166.5 & 0.002 \\
1999 & 64.26439 & 1794 & 9531.22 & 0.002 \\
2000 & 50.1919 & 2000 & 9725.22 & 0.002 \\
2001 & 84.77244 & 19406 & 9921.16 & 0.02 \\
2002 & 176.1442 & 61045 & 10120.98 & 0.03 \\
2003 & 274.1936 & 67795 & 10324.68 & 0.06 \\
\hline
\end{tabular}

Source: Central Statistical Organization 
$=0.02$

where, $X=$ the mean value of per capital income in kyat $\mathrm{Y}=$ the mean value of consumption in kilogram

\section{The factors affecting total rice productivity from 1987 to 2003 in Myanmar}

The most important determinants of total rice productivity, as suggested by most economic studies, appear to be: cropping intensity, the amount of loans distributed by MADB, the quantity of fertilizer utilization and the yield per unit area. The ARIMA (autoregressive integrated moving average) estimation procedure is used to estimate the productivity equation for rice. The analysis is based on economic theory and statistical properties.

Productivity determinants, Cropping Intensity (\%)

Cropping intensity is calculated by using the following equation. * 100

Cropping intensity = gross area sown/ net area sown

According to economic theory, there exists a direct relationship between the production area and total productivity. As the greater the production area, the productivity is likely to be high. Cropping intensity has been mainly increased by mean of summer rice cultivation during one growing season.

Productivity determinants, The amount of loan

According to economic theory, working capital plays crucial role affecting total productivity. Nearly all of the farmers are allowed to borrow agricultural loan from Myanma Agricultural and Development Bank (MADB). The total amount of loan provided by MADB from 1987 to 2003 was used in this analysis to determine how much amount of this variable contributed to Nation's rice productivity.

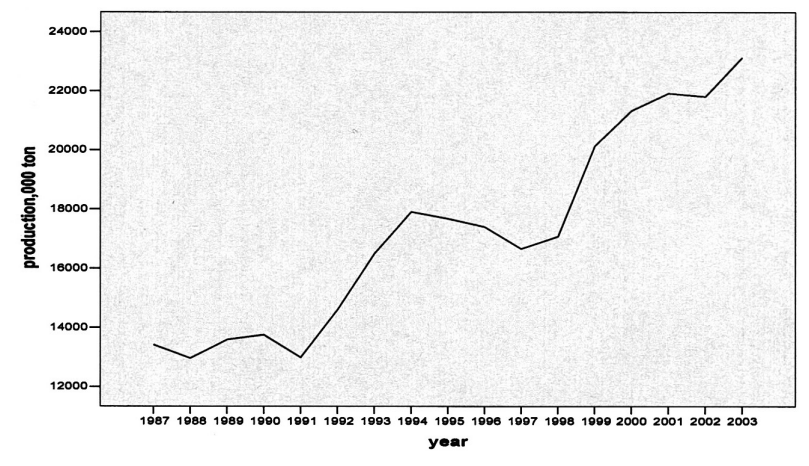

Central Statistical Organization, Yangon, Myanmar..

Fig. 4. Total rice production from 1987 to 2003.

In the model-building process, it is necessary to plot the total rice production from 1987 to 2003 as shown in Fig. 4 and look for any evidence that the mean or variance is not stationary. The series show global upward trend, making it clear that the level of the series is not stationary. Some degree of differencing will be necessary to stabilize the series level.

\section{Identifying Model}

Table (2) shows that the entire Box-Ljung statistic for the autocorrelation function (ACF) is statistically significant at any lag. This is not consistent with null hypothesis that the population autocorrelation function is 0 . In other word, the series level is not stationary because both ACF (Autocorrelation function) and PACF (partial autocorrelation function) is relatively far away from zero in Fig. 5. and Fig. 6. Thus, it indicates that non-seasonal differencing is necessary. After transforming the series by mean of natural log, there is no

Table 2. Autocorrelation of total rice production

\begin{tabular}{rccccc}
\hline \multirow{2}{*}{ Lag } & \multirow{2}{*}{$\begin{array}{c}\text { Autocorre- } \\
\text { lation }\end{array}$} & $\begin{array}{c}\text { Std. Error } \\
\text { (a) }\end{array}$ & \multicolumn{3}{c}{ Box-Ljung Statistic } \\
\cline { 4 - 6 } 1 & .807 & .223 & 13.136 & 1 & .000 \\
2 & .597 & .215 & 20.799 & 2 & .000 \\
3 & .393 & .208 & 24.365 & 3 & .000 \\
4 & .220 & .201 & 25.573 & 4 & .000 \\
5 & .059 & .193 & 25.666 & 5 & .000 \\
6 & .003 & .185 & 25.667 & 6 & .000 \\
7 & -.037 & .176 & 25.710 & 7 & .001 \\
8 & -.109 & .167 & 26.140 & 8 & .001 \\
9 & -.196 & .157 & 27.688 & 9 & .001 \\
10 & -.310 & .147 & 32.131 & 10 & .000 \\
11 & -.416 & .136 & 41.428 & 11 & .000 \\
12 & -.462 & .124 & 55.187 & 12 & .000 \\
13 & -.388 & .111 & 67.369 & 13 & .000 \\
14 & -.314 & .096 & 77.993 & 14 & .000 \\
15 & -.227 & .079 & 86.349 & 15 & .000 \\
\hline
\end{tabular}

a-The underlying process assumed is independence (white noise).

b-Based on the asymptotic chi-square approximation.

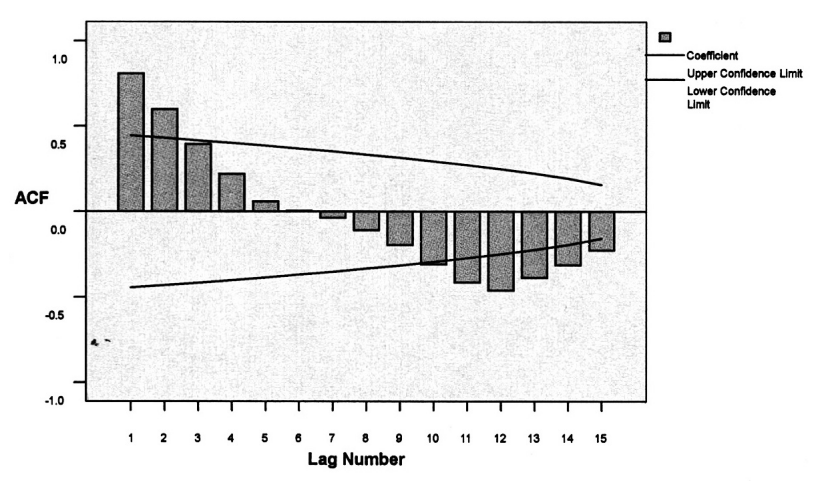

Fig. 5. Autocorrelation of total rice production in Myanmar.

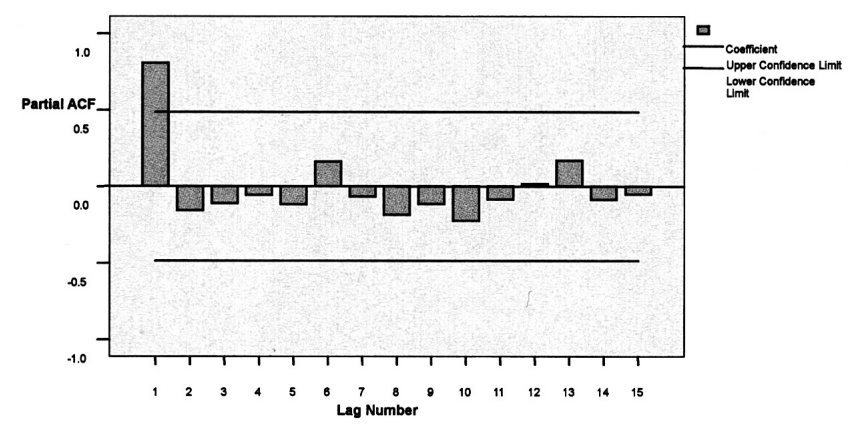

Fig. 6. Partial autocorrelation of total rice production in Myanmar. 
evidence that further non-seasonal differencing is required. The conclusion is that one order of non-seasonal differencing is sufficient for stabilizing the series. Now it is necessary to determine any autoregressive and moving average orders to model the series. According to the characteristic ACF and PACF patterns produced by non-seasonal process, it can be concluded that an ARIMA $(1,0,0)$ model may be most appropriate for this series.

\section{Creating the Model}

We have determined that a candidate model is ARIMA $(1,0,0)$ which is an AR model of differencing series. Therefore, constant term will represent the trend parameter. The residual diagnostics of AR model with parameter, total rice production and the parameter estimate without having predictors are elucidated in

Table 3. Residual diagnostics of AR model with the parameter, total rice production

\begin{tabular}{|c|c|c|c|}
\hline no. of residual & 17 & Residual Variance & 1616575.11 \\
\hline no. of parameter & 1 & $\begin{array}{l}\text { Model } \\
\text { Std. } \\
\text { error }\end{array}$ & 1271.45 \\
\hline $\begin{array}{l}\text { Residual } \\
\text { d.f }\end{array}$ & 15 & $\begin{array}{l}\text { Log } \\
\text { likelihood }\end{array}$ & -145.87 \\
\hline $\begin{array}{l}\text { Adjusted } \\
\text { Residual Sum of } \\
\text { Squares }\end{array}$ & 28234529.29 & $\begin{array}{l}\text { A.I.C } \\
\text { Alkaike's Information } \\
\text { Criterion }\end{array}$ & 295.74 \\
\hline $\begin{array}{l}\text { Residual Sum of } \\
\text { Squares }\end{array}$ & 35356442.53 & $\begin{array}{l}\text { B.I.C } \\
\text { Schwarz's Bayesian } \\
\text { Criterion }\end{array}$ & 297.41 \\
\hline
\end{tabular}

Parameter estimate

\begin{tabular}{lllll}
\hline & Estimates & Std Error & t-value & $\begin{array}{l}\text { Approx } \\
\text { Sig }\end{array}$ \\
\hline Non-Seasonal Lags AR1 & .96 & .06 & 15.58 & .00 \\
Constant & 18011.35 & 4045.66 & 4.45 & .00 \\
\hline
\end{tabular}

Table 4. Autocorrelation of total rice production after transforming the series by means of natural log

\begin{tabular}{rrrrrr}
\hline & \multirow{2}{*}{$\begin{array}{c}\text { Autocorre- } \\
\text { lation }\end{array}$} & Std. Error & \multicolumn{3}{c}{ Box-Ljung Statistic } \\
\cline { 4 - 6 } & & (a) & Value & $\mathrm{df}$ & Sig. (b) \\
\hline 1 & .232 & .223 & 1.085 & 1 & .298 \\
2 & -.085 & .215 & 1.242 & 2 & .538 \\
3 & -.084 & .208 & 1.404 & 3 & .705 \\
4 & .096 & .201 & 1.635 & 4 & .803 \\
5 & -.103 & .193 & 1.923 & 5 & .860 \\
6 & -.070 & .185 & 2.066 & 6 & .913 \\
7 & -.003 & .176 & 2.067 & 7 & .956 \\
8 & .011 & .167 & 2.072 & 8 & .979 \\
9 & .075 & .157 & 2.297 & 9 & .986 \\
10 & .144 & .147 & 3.249 & 10 & .975 \\
11 & -.030 & .136 & 3.299 & 11 & .986 \\
12 & -.365 & .124 & 11.924 & 12 & .452 \\
13 & -.134 & .111 & 13.381 & 13 & .419 \\
14 & -.043 & .096 & 13.576 & 14 & .482 \\
15 & -.001 & .079 & 13.576 & 15 & .558 \\
\hline
\end{tabular}

a- The underlying process assumed is independence (white noise).

b- Based on the asymptotic chi-square approximation.
Table 3. Moreover, the coefficient of Non-Seasonal Lags (AR1) is significant at $1 \%$ level.

\section{Model Diagnosis}

Diagnosing an ARIMA model is a crucial part of the model-building process and involves verifying that the residuals are random. The most direct evidence of random residual is the absence of significant value of the Box-Ljung Q statistic at lag of about one quarter of the sample size. Since the current sample size is 17 , we should analyze values in the region of the lag 4 statistic.

Table 4 shows that none of the Box-Ljung value in the vicinity of lag 4 is significant. This confirms that the residuals for the ARIMA $(1,0,0)$ model are random, which also means that no essential components have been omitted from the model. Furthermore, both ACF and PACF are not significantly far away from zero in Fig. 7 and Fig. 8.

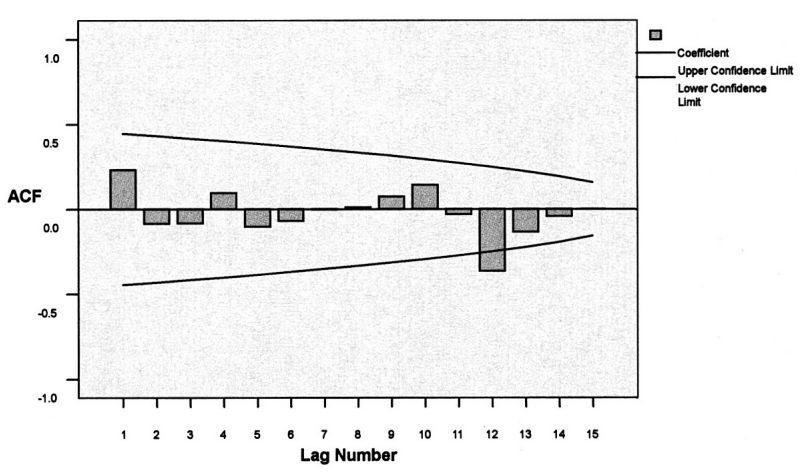

Fig. 7. Error for total rice production from ARIMA (autocorrelation function).

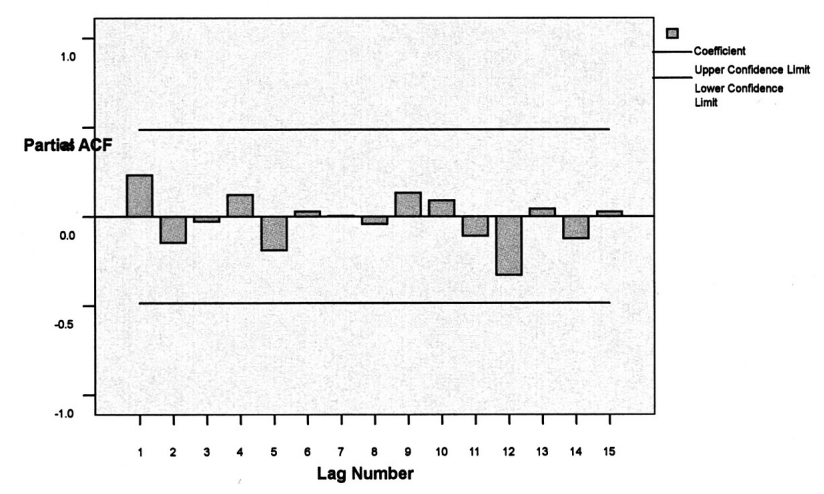

Fig. 8. Error for total rice production from ARIMA (Partial ACF).

\section{Adding predictors to the Model}

It is necessary to determine that an ARIMA $(1,0,0)$ model does a good job of capturing the structure of the time series; however, the model is based only on the series itself and doesn't incorporate information about the possible predictors series included with the original data set. We need to build a better forecasting model by total rice production as a dependent variable and treating variables, such as cropping intensity, the amount of loan distributed by MADB, the quantity of fertilizer utilization and the yield per unit area. ARIMA treats these predictors or independent variables much like 
predictor variables in regression analysis- it estimates the coefficient for them that best fit the data.

\section{RESULTS AND DISCUSSION}

\section{The relationship between the seasonal price and net farm returns on Rice production}

Seasonal Index is measured by Ratio-to-MovingAverage Method. All index number are then stated relative to the average 100 index number. From the figure it is possible to quickly observe the period of time during which the rice price level was moving up rapidly; for example, from June through November the index gained 13.98 points. This information could then be related to the economic information of those periods to form a picture of the general economic situation existing at that time. For example, this period is likely to be coincident with the period of monsoon rice cultivation. Farmers could make higher profit if they sell their products during this period. In order to have such kind of profit, farmers must have the storage facilities and retaining ability to store their products for at least 6 months before they sell their products. It can be seen that the period of time from November through February during which the rice price level was going down steadily from the index number 108.95 to 94.68 . This is due to the fact that the monsoon rice was harvested during this period and the supply of rice is likely to be higher than demand because most of the farmers need extra cash in order to repay their loan before the interest makes them heavy burden. After that period, the price index remained fairly stable but below the average during the period from the February to June. This reveals that the output of summer rice cultivation is available during this period. As a result, the price of rice is steadily going below the average price until the beginning of monsoon rice cultivation. After that period, the price index has started to go up until the monsoon rice is harvested. It can be found that the price of summer rice is somewhat lower than that of monsoon rice because of their specific quality and consumer preference. Since the income variation is partially impacted by the seasonal fluctuation of rice price, it would be interesting to know which factors are mainly contributing to the fluctuation of rice price. In order to achieve this issue, it is necessary to determine the demand schedule for Myanmar. In other words, the interrelationship among rice price, income per capital and consumption of rice should be considered.

\section{Demand schedule of rice for Myanmar}

The price elasticity of demand is used to determine whether total revenue will change when the prices are raised or lowered. Since the elasticity of demand $(\mathrm{E})$ is $0<\mathrm{E}<1$, it can be concluded that the demand is inelastic. In other words, there has been no association between the changes in consumption and the changes in price of rice throughout the period from 1997 to 2003. Therefore, it can be said that there has been no changes in the consumption of rice in Myanmar no matter how much the price changes. For inelastic demand, as price increases, total revenue increases. Therefore, the farmers would achieve higher revenue if the price rises to some extent.

In our case, we calculated the income elasticity of demand to be 0.02 so rice is income inelastic and a normal good and thus demand is not very sensitive to income changes. Therefore, it can be said that there would be no changes in amount of consumption of rice no matter how much income the consumers earn. Since both the price elasticity and income elasticity of demand for rice are likely to be inelastic, it can be confirmed that rice is likely to be a main staple food in Myanmar.

\section{The factors affecting total rice productivity from 1987 to 2003 in Myanmar}

The parameters estimate table (5) provides estimates of the model parameters and associated significant values, including AR order as well as any predictors. Notice that the parameter representing the nonseasonal Auto regression component (label AR) is significant. This is expected, since we have already determined that it should be part of the model. The variables representing the quantity of fertilizer utilization and the amount of loan distributed by MADB are not significant. In fact, the only significant predictors are the percentage of cropping intensity and the yield per unit area. Since AIC and BIC statistics of the model with predictors seem to be much lower than that of the model without having predictors, AR model having predictors is found to be more efficient.

Table 5. Residual diagnostic of AR model after adding independent variables

\begin{tabular}{llll}
\hline no. of residual & 17 & Residual Variance & 0.001 \\
\hline no. of parameter & 1 & $\begin{array}{l}\text { Model } \\
\text { Std. } \\
\text { error }\end{array}$ & 0.03 \\
\hline $\begin{array}{l}\text { Residual } \\
\text { d.f }\end{array}$ & 12 & $\begin{array}{l}\text { Log } \\
\text { likelihood }\end{array}$ & 34.83 \\
\hline $\begin{array}{l}\text { Adjusted } \\
\text { Residual Sum of } \\
\text { Squares }\end{array}$ & 0.02 & $\begin{array}{l}\text { A.I.C } \\
\text { Alkaike's Information } \\
\text { Criterion }\end{array}$ & -59.66 \\
\hline $\begin{array}{l}\text { Residual Sum of } \\
\text { Squares }\end{array}$ & 0.13 & $\begin{array}{l}\text { B.I.C } \\
\text { Schwarz's Bayesian } \\
\text { Criterion }\end{array}$ & -55.49 \\
& & &
\end{tabular}

Parameter estimate

\begin{tabular}{llllll}
\hline & & Estimates & $\begin{array}{l}\text { Std } \\
\text { Error }\end{array}$ & t & $\begin{array}{l}\text { Approx } \\
\text { Sig }\end{array}$ \\
\hline Non-Seasona & AR1 & 1.00 & .00 & 3269.10 & .00 \\
l Lags & Fertilizer & $5.88 \mathrm{E}-005$ & .00 & .509 & .62 \\
Regression & (000MT) & .005 & .00 & 2.67 & .02 \\
Coefficients & Cropping & $-7.99 \mathrm{E}-007$ & .00 & -.19 & .84 \\
& intensity (\%) & .221 & .08 & 2.75 & .01 \\
& loan (million & & & \\
& kyat) & & & \\
& Yield (ton/ha) & & & \\
\hline
\end{tabular}

Melard's algorithm was used for estimation. Dependent variable: total productivity (000, metric ton) 
According to the statistical data results, AR 1 model is statistically significant at $1 \%$ level. Unfortunately the fertilizer utilization and the amount of loan distributed by MADB are statistically insignificant. This is due to the facts that fertilizer usage from 1987 to 2003 is likely to be fluctuated. Although the amount of fertilizer utilization trend is leading downward, the total rice production is not significantly decreased and the trend was going steadily. As a result there is no relationship between the amounts of fertilizer utilization and total rice production. The trend of loan distribution is steadily increased during this period. But it can be seen that the loan distribution variable is not statistically significant on the contribution of total rice production because the amount of loan per unit acre is not likely to be enough to cover the optimum production cost. If we consider the significant variables such as cropping intensity and the yield per unit acre, it can be found that the trend of cropping intensity has been moving up during this period. This upward trend is mainly influenced by the expansion of summer rice cultivation during one growing season. As a result, the total rice cultivation acres per unit area are sharply increased which in turn contributes the total rice productivity. The coefficient of cropping intensity has the value of 0.005 , which can be interpreted to mean that an increase of $1 \%$ in cropping intensity will lead to a 5 metric ton increase in the Nation's rice productivity with the effect of all variables held constant. The t- ratio of 2.67 is significant at 5\% level of significance. Therefore it can be concluded that the Nation's rice productivity is mainly impacted by the cultivation of summer rice after harvesting monsoon rice during one growing season. Another important factor on the determination of total rice productivity is yield per unit acre. The coefficient of this variable has the value of 0.221 , which can be interpreted to mean that holding all other factors constant, an increase of 1 ton per hectare in yield will lead to 221 metric ton in Nation's rice productivity. The t-ratio of 2.76 turns out to be significant at 5\%level of significance. The significance of this variable seems to have no surprise on the contribution of Nation's rice productivity because the trend of yield per unit acre is steadily increased as the total productivity increased. In the conclusion, the combine effect of high cropping intensity and high yield per unit acre is likely to be impacted on the Nation's rice productivity during the period from 1987 to 2003.

\section{CONCLUSION AND RECOMMENDATION}

This result of nationwide analysis of the period from 1997 to 2003 depicted that the rise in price would increase the total revenue of farmers because the price elasticity of demand for rice in Myanmar is inelastic. At the same time, the efficient and suitable pricing policy should be applied in order for the consumers to access the reasonable price for rice. In addition to give concerted effort to increase productivity in term of cropping intensity, the adaptable support program for the capability of accessing essential agricultural inputs should be provided to increase the yield per unit area.

\section{REFERENCES}

Aaron C. J., M. B. Johnson. Johnson and R. C. Buse; 1987 Econometrics, Basic and Applied, Macmillan, New York.

Andy. F. 2000 Discovering statistics using SPSS for windows, SAGE publication, London and Macmillan, New York

Central Statistical Organization, 1999 Agricultural Statistics 1987-88 to 1997-98 Ministry of National Planning and Economic Development in Collaboration with Department of Agricultural Planning, Ministry of Agriculture and Irrigation, Yangon, Myanmar.

Central Statistical Organization, 2001 Statistical Yearbook, Yangon, Myanmar.

Central Statistical Organization, Selected Monthly Economic Indicators from 2001 to 2005, Yangon, Myanmar.

DAVID L. D.; 1986 Agricultural Production Economics, Macmillan publication, New York, Collier Macmillan, London.

DAVID N. H. 1993 Modern Microeconomics (Analysis and Applications) (Third Edition), Homewood, IL: Irwin.

Department of Agricultural Planning, Myanmar Agricultural at a Glance from 2003 to 2005, Ministry of Agriculture and Irrigation, Myanmar.

Donald J. E. and J. W. Malone 1981 Introduction to Agricultural Economics, Macmillan, New York and Collier Macmillan, London.

Jeremy. J. F. 2001 Data analysis using SPSS for windows version 8 to 10, SAGE publication, London.

Kiet N. T. 1963 A study of rice price (Research paper), Department of Agriculture Economics, Michigan State University. From the Website of http://agecon.lib.umn.edu/cgi-bin/pdf_ view.pl?paperid=11185.

Morgan G.. A., V. G.. Orlando and G. W. Glreckner 2001 SPSS for Windows: An introduction to use and Interpretation in Research, Mahwah, N. J.: Lawrence Erlbaum Associates.

Rod. C. and A. Colman 2003 A crash course in SPSS for windows Second edition Updated for versions 10 and 11, Blackwell, Oxford. 